\title{
Leverage Deviations and Acquisition Probability in the UK: The moderating effect of firms' internal capabilities and deal diversification potential
}

In the context of mergers and acquisitions, we provide evidence to suggest that a firm's deviation from its optimal financial leverage may impede its ability to undertake future expansions. We also find the negative effect of leverage deviation on acquisition probability to be moderated by firms' existing capabilities. Further, we find those deviating firms to have better prospects of achieving growth when they pursue cross-industry and/or cross-country mergers and acquisitions. Overall, our findings imply that deviations from the optimal financial leverage may be costly to firms but this cost is not symmetric across all firms and all deal types.

Keywords: optimal leverage; industrial diversification; geographic diversification; internal capabilities; mergers and acquisitions (M\&A).

\section{Introduction}

The link between corporate financial and diversification strategies has long been an important research issue in the finance and management literature (see Barton \& Gordon, 1988; Doukas \& Kan, 2008; Krapl, 2015; Agyei-Boapeah, 2015). For instance, Barton \& Gordon (1988) propose that since a firm’s diversification strategy may reflect the risk appetite of top managers, diversification should be related to financial leverage. This paper contributes to this literature on the leverage-diversification link by investigating how committing to undertake diversifying acquisitions (relative to non-diversifying ones) may influence the financing constraints that may be faced by firms that deviate from their optimal (target) leverage ratios. ${ }^{1}$

Drawing on the trade-off theory of capital structure (see, Myers, 1977; Uysal, 2011) and the managerial inefficiency theory of mergers and acquisitions (M\&As) (see Manne, 1965; Jovanovic \& Rousseau, 2002), we argue in this article that extreme deviations from the optimal leverage ratio (i.e.

\footnotetext{
${ }^{1}$ Although "target leverage" and "optimal leverage" are used synonymously in the finance literature, in this article about M\&As, we restrict ourselves to the term "optimal leverage" in order to avoid any potential confusion of erroneously interpreting the target leverage to mean the leverage of the acquired firm. This confusion may arise because the "acquired firms" are often referred to as the "target firms" in the M\&A literature.
} 
leverage deviations) may represent an inefficient management action which can hamper the initiation and successful completion of M\&As. Despite theoretical predictions, the direct link between leverage deviation and the ability to undertake M\&As remained largely unexplored until recently when Uysal (2011) utilised data on US domestic acquisitions to show that firms with leverage deviations are unable to aggressively bid for acquisition targets, which ultimately impedes their ability to complete domestic acquisitions.

The present article relates to, but also differs in a number of ways from the prior study by Uysal (2011). First, while the prior study was restricted to only domestic acquisitions made by US firms, this article examines the link between leverage deviation and acquisition probability within a framework that incorporates both domestic and cross-border acquisitions. Given the surge in the volume of cross-border acquisitions from 23\% in 1998 to about 45\% in 2007 (Eriel et al., 2012), and the fact that cross-border acquisitions tend to be larger and rely more on external financing (Agyei-Boapeah, 2015), the exclusion of cross-border acquisitions from the prior study presents a partial view of the association between leverage deviation and acquisition probability. This paper is, therefore, the first to present a relatively more complete view of the link between leverage deviation and acquisition probability by examining both domestic and cross-border acquisitions.

Second, to date, most of the existing empirical research on leverage deviation has been conducted in the US context. The extent to which the explanations offered in the US context hold in other countries remains largely unknown. A notable exception is the recent study by Ahmed \& Elshandidy (2018) which explores why overleveraged British firms prefer foreign over domestic acquisitions. While they make an important contribution to the leverage deviation literature from a UK context, their focus and approach did not permit them to be directly address the primary issue of acquisition probability (i.e. the ability to successfully undertake acquisitions), as well as tackle how other forms of leverage deviations (i.e. underleveraging, moderate- and extreme-leverage deviations) might differently impact 
acquisition probability. Our paper directly addresses these issues within the UK context, thereby, offering results that can easily be compared with prior US findings.

Like the US, the UK is very active in the market for corporate control, which offers us sufficient M\&A observations for a robust analysis. The UK, for example, was the largest acquiring country globally in 2000 (UNCTAD, 2000). Therefore, the contribution we make to the literature by focusing on UK firms is significant because due to the institutional heterogeneity across countries, capital structure decisions tend to vary across countries (Rajan \& Zingales, 1995; Antoniou et al., 2008). While the UK has a vibrant market-based financial system which is similar to the US (see Antoniou et al., 2008), the UK's capital market is relatively smaller and less liquid than the US, suggesting that financial constraint may be a more serious problem for UK firms compared to their US counterparts. ${ }^{2}$

Third, despite the possibility for investors to react differently to various types of investment projects, the prior studies on the link between leverage deviation and financing/investments have often failed to distinguish between the impact of firms' leverage deviations on diversifying and nondiversifying investments (e.g. Hovakimian et al., 2001; Kayhan \& Titman, 2007; Harford et al., 2009; Uysal, 2011). Ahmed \& Elshandidy (2018) show that overleveraged firms are more likely to diversify globally to create value for their shareholders, implying that investors may be more willing to fund M\&A deals that expand the firms' global diversification. Our paper adds to this literature by suggesting that since some investors find merit in synergistic diversification moves (see Lewellen, 1971; Doukas \& Kan, 2008), while others frown upon diversifying expansions (e.g. Lang \& Stulz, 1994), firms with leverage deviation that undertake M\&As may face relatively lower or higher costs depending on the diversification characteristic of the proposed M\&A deal. It is noteworthy that our contribution in this respect is not limited to global diversification, but extends to industrial diversification as well.

\footnotetext{
${ }^{2}$ The 2012 data from the World Development Indicators of the World Bank suggests that the financial market in the US is about 9 times bigger than that of the UK, when the size of the financial market is measured by market capitalisation (i.e. $\$ 21.4$ trillion vs. $\$ 2.5$ trillion). The data also suggest that the US has a more liquid financial market compared to the UK (i.e. stock turnover ratios of $125 \%$ vs. $84 \%$ ).
} 
Finally, we draw on the resource-based view (RBV) of the firm (see Barney, 1991; Teece et al., 1997) to investigate how the effect of leverage deviation on acquisition probability may be conditional on the firm's internal capabilities such as management skills/ability, organisational culture/processes as well as technological know-how and innovation. These firm-idiosyncratic capabilities are not only a source of competitive advantage but could also be crucial in making M\&As a real value-enhancing strategy. Thus, we posit that firms with superior existing (non-financial) resources/capabilities may be able to reduce the leverage deviation costs and consequently mitigate any potential impact on acquisition ability. This final contribution that we seek to make to the literature is novel since, to the best of our knowledge and extensive literature search, the prior related studies, thus far, have not addressed it.

Our empirical analysis provides evidence to suggest that inefficient (sub-optimal) managers who disregard their firms' optimal leverage ratios tend to have a significantly lower ability to undertake M\&As. We further find that the cost of deviating from the optimal leverage is asymmetrically higher for: (1) overleveraged firms relative to underleveraged firms, and (2) extreme deviant firms relative to moderate deviant firms. In addition, we find the negative effect of leverage deviation on acquisition probability to be moderated by firms' existing levels of (non-financial) resources/capabilities. Finally, we find that firms with leverage deviation have a better chance of completing diversifying acquisitions (i.e. cross-industry and cross-border acquisitions) relative to non-diversifying acquisitions (i.e. withinindustry and domestic acquisitions). These findings have important implications for both theory and practice in corporate policy. Firstly, the results provide support for the relevance of the optimal leverage ratio and the trade-off theory of capital structure, as well as, the inefficient management theory of M\&As by suggesting that deviations from the optimal leverage may hinder firms' ability to undertake investment projects. Further, the findings imply that firms that deviate from their optimal leverage have better prospects of successfully completing acquisitions when they have superior firm-specific capabilities and/or when they select acquisition deals that have the potential to diversify their cash flows across industries and geographic scope (i.e. cross-industry and cross-border acquisitions). 


\section{Related literature and hypotheses development}

M\&As as a means for firm growth

This study first explores how a firm's deviation from its optimal leverage influences its ability (and/or incentive) to invest and grow by M\&As. Although firms can grow by some other means such as internal development and cooperation (e.g. joint ventures), this article focuses on M\&As whose speed (over internal development) and full control over resources (relative to cooperation) often make them advantageous strategic tools for managers to achieve firms’ expansion (Eschen \& Bresser, 2005).

Arguably, these unique features of M\&As (speed and full control) make them an attractive growth strategy for managers, and perhaps explain why M\&As remain a popular corporate expansion strategy and continue to receive research attention. We contribute to this immense literature on M\&As, in particular, the research on the drivers of M\&A decisions. Existing research on the managerial motives (incentives) for undertaking M\&As broadly classifies the drivers of M\&A decisions into two, i.e., synergy-based theories and non-synergy motives. The latter involves agency-motivated (Jensen, 1986; Morck, Shleifer \& Vishny, 1990) or hubris-driven (Roll, 1986) deals that often result in valuedestroying M\&As.

By contrast, the synergy-based literature (e.g. Stigler, 1964; Manne, 1965; Jovanovic \& Rousseau, 2002; Eschen \& Bresser, 2005) proposes that M\&As are planned and executed by managers to create, increase or maximize shareholders' wealth, and thus value-maximizing (efficient) managers are more likely to undertake acquisitions. The potential sources of synergistic gains from M\&As vary and may include: (1) increasing market power (Stigler, 1964); (2) augmenting the firm's strategic resource position (Eschen \& Bresser, 2005); (3) eliminating managerial inefficiency (Manne, 1965; Jovanovic \& Rousseau, 2002); and (4) achieving financing advantages by exploiting unused debt capacity of the other merging firm (Ghosh \& Jain, 2000), or improving the merged firm’s debt capacity (Lewellen, 1971). 
Altogether, to the extent that investors support value-enhancing M\&As, then the synergy-based theories (particularly the managerial inefficiency theory) posit that better and efficient managers (for acquiring firms) are more likely to obtain the necessary financing to undertake M\&As. Within this theoretical context, the current study examines whether the sub-optimal management of the firm's capital structure (via deviations from the optimal leverage) adversely influences the firm's ability/incentive to undertake M\&As.

Leverage deviation, access to financing, and M\&As

The first question that we ask and seek to answer is whether there a relationship between a firm's deviation from its optimal leverage ratio and its ability to undertake M\&As. Addressing this question is important and deserves attention because while several motives for M\&As exist, arguably, M\&As can only occur if the acquiring firm is able to raise funds to finance the deal. Despite the crucial role of financing in the firm's decision to undertake acquisitions, the financing of M\&As remains understudied, and the scant literature on the matter is largely about the abnormal announcement returns associated with the method of payment (see e.g. Martynova \& Renneboog, 2009). We extends this literature by exploring how a firm's past financing policies may create future financing constraint for it, and subsequently influence its ability to undertake acquisitions. Although availability of financial resources is important in almost all types of corporate expansions, it perhaps becomes more crucial for growth by M\&As due to the relatively shorter window within which acquisitions are to be negotiated and completed once a potential target becomes available.

Our central argument in this paper is that extreme deviations from the optimal leverage ratio may be associated with lower acquisition likelihood because extreme leverage deviations may be viewed by capital providers as sub-optimal (i.e. an inefficient management action) which then creates financing constraints for firms with such sub-optimal managers. Underpinning this argument is the trade-off theory of capital structure which predicts that firms should maintain optimal leverage ratios because the 
optimal leverage ratio maximizes the value of the firm (see, e.g. Myers, 1977; Uysal, 2011). An important implication is that firms that deviate from their optimal leverage ratios could face some substantial costs since they may be viewed by investors as being "non-maximizers" of firm value. One such costs of leverage deviation (i.e. deviations from the optimal leverage) is financing and investment constraints (see, Hovakimian et al., 2001; Kayhan \& Titman, 2007; Harford et al., 2009; Uysal, 2011).

Leverage deviations may be positive (i.e. firms may overleverage) or negative (i.e. firms may underleverage), but much of the existing empirical literature suggests that the cost of overleveraging is higher than that of underleveraging (van Binsbergen et al., 2010; Uysal, 2011). Perhaps, this is because the bankruptcy costs associated with overleveraging may be regarded by investors to be a more serious problem than the cost of forgoing the tax savings associated with underleveraging. Consequently, a bulk of the existing empirical evidence supports the conjecture that it is overleveraging (but not underleveraging) that is associated with financing and investment constraints (see Hovakimian et al., 2001; Harford et al., 2009; Uysal, 2011). For example, Harford et al. (2009) show that overleveraged firms are less (more) likely to finance acquisitions with debt (equity). Given that the cost of equity capital is generally higher than the cost of debt capital (see Lee et al., 1996), these findings imply that overleveraged firms are likely to finance their investments at a relatively higher cost of capital, and may thus face external financing difficulties, which could, in turn, constrain their investments.

Besides the external (debt) financing constraints, it has also been suggested that high-leveraged firms may also face internal financing constraints (see Jensen, 1986), since debt capital commits managers to regularly pay out cash flow as interest payments, thereby, restricting the availability of corporate funds at the disposal of managers. The existing empirical evidence largely shows a negative (positive) association between high leverage (low leverage) and M\&A activities (Ghosh \& Jain, 2000), implying that overleveraged (underleveraged) firms are more (less) likely to face financial/investment constraints. 
A common feature of the empirical studies so far has been the fact that they distinguish between the direction of deviation (i.e. overleveraging or underleveraging) without any attempt at considering the extent of deviation (i.e. extreme deviation or moderate deviation) from the optimal leverage ratio. Focusing on the extent of deviation from the optimal leverage is important because the cost of leverage deviation is likely to vary with the absolute distance between a firm's actual and optimal leverage ratios (Fischer et al., 1989). In fact, it is possible for some overleveraged firms to be very close to the optimal capital structure, in which case they are unlikely to face severe financial/investment constraints. Thus, the documented link between overleveraging and financing/investment constraints may only be restricted to those overleveraged firms that aggressively/extremely go beyond their optimal leverage ratios.

Similarly, it may be the case that underleveraged firms that substantially stay below their optimal leverage ratios may be representative of those firms that are unable to attract external debt capital. While moderate and occasional underleveraging may be a strategic choice by managers to store up debt capacity for future investments (Ghosh \& Jain, 2000; DeAngelo et al., 2011), extreme and persistent underleveraging could indicate poor management (i.e. inefficient capital structure policy), or represent firms with inferior growth opportunities, all of which can lead to financing/investment constraints. Empirically, Elsas \& Florysiak (2011) show that both extreme under- and over-leveraged firms face asymmetrically higher deviation costs (i.e. cost of staying suboptimal) than moderately under- and overleveraged firms. ${ }^{3}$ In sum, deviation costs are greater when firms are further away from (either above or below) the optimal leverage ratio and, therefore, both extreme under- and over-leveraging may be costly to firms.

On the basis of the foregoing discussions, unlike most prior studies on leverage deviation, the current article considers the relationship between the extent of leverage deviation (i.e. moderate deviation and extreme deviation) on the one hand and financing/investment constraints on the other

${ }^{3}$ Elsas \& Florysiak (2011) report that the speeds of adjustment towards leverage targets, which denote the deviation costs, are $36 \%, 38 \%, 45 \%$, and $50 \%$ for moderately underleveraged firms, moderately overleveraged firms, extremely underleveraged firms, and extremely overleveraged firms, respectively. 
hand. We contend that because the firm's value is maximized at the optimal level of leverage, any substantial and systematic departure from the optimal leverage ratio (whether above or below) is likely to be associated with financing constraints, which, in turn, could restrict the firms' ability to undertake M\&As.

Finally, it is plausible that extremely underleveraged firms have no present borrowing needs because they, perhaps, face limited investment opportunity sets. This is because firms generally resort to the external capital market for funds only when the value of their planned investments exceeds their available internal funds. So, extremely underleveraged firms may represent those firms that have no immediate borrowing needs. Similarly, extremely overleveraged firms may have exhausted their growth opportunities by borrowing to invest in the past. Taking such a perspective makes extremely under- and over-leveraged firms inferior firms (i.e. low q firms), thus, unlikely to become acquirers according to the managerial inefficiency theory of M\&As. In the end, consideration of the view on limited investment opportunities still lead us to predict a negative relationship between leverage deviation and acquisition probability. However, in order to reduce any possibility of the limited opportunity set explanation masking our financing constraint arguments, we are careful to specifically control for the firms' growth opportunities in our empirical analyses.

Overall, if extreme deviations from optimal leverage represent sub-optimal management action (as predicted by the trade-off theory of capital structure) and sub-optimal managers are less likely to become acquirers in M\&A transactions (as predicted by the management inefficiency theory of M\&As), then we hypothesise as follows:

Hypothesis 1: There is a negative relationship between leverage deviation (particularly extreme deviations) and the probability of undertaking acquisitions. 
We draw from the resource-based view (RBV) of the firm to suggest that the average cost of leverage deviation may be lower for firms that possess superior internal capabilities, and therefore, have the potential to convert M\&A opportunities into value-creating strategies for shareholders. We argue that such firms, even when they deviate from the optimal leverage, may be treated preferentially by investors - i.e., investors may deny funds to deviant firms with inferior internal capabilities, but not to their counterparts with better capabilities.

The RBV emphasizes the importance of idiosyncratic firm attributes (capabilities and resources) in shaping firms' competitive advantage and their ability to implement value-creating strategies (Barney, 1991; Teece et al., 1997). The theory suggests that firms tend to derive competitive advantage through their ownership and control of resources/capabilities that are often rare, intangible, and highly valued by investors (Barney, 1991). These resources/capabilities include managerial skills/abilities, organisational culture/dynamism, technological know-how and innovation capabilities (see Barney, 1991; Teece et al., 1997). Clearly, the availability of these valuable (intangible) organisational resources/capabilities equips the firm to effectively deal with its challenges including financial constraints and devise appropriate actions to neutralise them.

Given that such valuable resources are heterogeneously distributed across firms, the RBV suggests that differences in resource/capabilities endowment may influence firms' growth prospects, ability to extract more synergistic gains from M\&As, and hence, attractiveness to investors. Following the RBV, we posit that the negative effect of leverage deviation (i.e. financing constraints) on firm growth will decrease with internal capabilities derived from a portfolio of organisational resources. Thus, we submit that firms with higher internal capabilities are unlikely to have their ability to complete acquisitions impeded when they deviate from the optimal leverage. Accordingly, Hypothesis 2 is formulated for testing.

Hypothesis 2: The negative effect of leverage deviation on the probability of undertaking acquisitions is mitigated for firms with superior internal resources/capabilities. 
The industrial diversification hypothesis

Diversification theory provides numerous explanations as to why firms diversify; including agency reasons, development of internal capital markets, obtaining co-insurance benefits and increased market power [see Erdorf et al. (2013) for a review of diversification theories]. Taking a strategic management perspective and emphasizing the agency, market power, and resource-based theories, some empirical studies show that diversifying (cross-industry) expansions may be less value-enhancing compared to related (within-industry) expansions (e.g. Montgomery \& Singh, 1984; Morck et al., 1990). For instance, Montgomery \& Singh (1984) argue that the potential for synergistic gains is greater in withinindustry expansions due to the better strategic fit in manufacturing processes, marketing requirements, research and managerial tasks across the various related segments of the organisation. From this perspective, proposing to undertake cross-industry (diversifying) acquisitions, relative to withinindustry acquisitions may be viewed less favourably by investors. Similarly, the research examining the value impact of industrial diversification by comparing the value of diversified firms to their focused counterparts almost unanimously document the existence of a diversification discount, suggesting that (on average) firms destroy value by engaging in diversifying expansions (e.g. Lang \& Stulz, 1994).

However, recent studies point out that the value of diversification to firms differs over time, particularly depending on the prevailing economic environment. Erdorf et al. (2013) note that since financial constraints are more binding during recessions, the value of diversification is higher during recessionary periods when there is limited credit on external capital markets. Consistent with these conjectures, prior research (e.g. Yan et al., 2010; Kuppuswamy \& Villalonga, 2016) provides evidence of substantial value for diversified firms during periods of depressed external capital markets. Kuppuswamy \& Villalonga (2016) report that the value of diversified firms relative to focused firms increased by $4-5 \%$ during the recent 2007-2009 financial crisis. They further provide evidence that attributes these diversification gains to significant increases in conglomerates' leverage (i.e. borrowing 
ability) relative to comparable portfolios of focused firms, and to improved efficiency of internal capital markets. Finally, they show that these gains are restricted to cross-industry diversifiers, and do not extend to within-industry diversifiers.

Lewellen's (1971) co-insurance theory explains why pursuing a cross-industry (unrelated) diversification strategy may be associated with financing advantages. He submits that M\&As, especially diversifying (conglomerate) mergers, create a combined entity that has less volatile cash flows compared to the pre-merger firms acting separately. This reduced volatility, he notes, is due to the co-insurance effect that may exist when the cash flows of acquirers and target firms are less than perfectly positively correlated. Since cash flows are less (more) positively correlated among firms in different (the same) industries, the co-insurance benefit should be greater (lesser) for firms that diversify into different (same) industries. Thus, the enhanced stability in cash flow due to the coinsurance effect should translate into financing advantages (i.e. improved borrowing capacity) for cross-industry diversifiers. Empirically, Singhal \& Zhu (2013) find that diversification reduces the probability of a firm filing for bankruptcy while Hann et al. (2013) show that industrial diversification reduces firms' cost of capital by reducing their systematic risk. These findings imply that lenders tend to be more confident in supplying funds to diversified firms than to focused firms.

While the financing advantages enjoyed by diversified firms over their focused counterparts are obvious, those of pursuing cross-industry (diversifying) M\&As as opposed to within-industry (related) M\&As may seem less obvious. Thus, we specifically point out how undertaking cross-industry M\&As (but not within-industry M\&As) may be financially beneficial to constrained firms. Firms borrow today and expect to pay back out of their future cash flows which depend on the type of investments they undertake. So lenders may supply capital to financially constrained firms today (to possibly fund their M\&As) giving consideration to how the proposed investments (e.g. cross-industry vs. within-industry) impact their future cash flows. To the extent that making cross-industry M\&As increases the firm's business segment unrelatedness, this type of investment should improve future cash flow stability 
(Lewellen, 1971), reduce default risk (Singhal \& Zhu, 2013), and enhance borrowing capacity (Kuppuswamy \& Villalonga, 2016). The overall effect, consequently, is a relaxed financing/investment constraint for firms making cross-industry acquisitions, but not for those undertaking within-industry acquisitions.

Similar conclusions can be reached from the inefficient (poor) management perspective. If firms with extreme leverage deviations are considered to be poor performers in their existing industries, then they may have a greater incentive to seek diversifying (cross-industry) expansions, since Morck, Shleifer \& Vishny (1990) and Lang \& Stulz (1994) suggest that poor performers have an incentive to enter new lines of businesses. Therefore, diversifying expansions seem to present new growth opportunities to poor performers (e.g. firms with limited investment opportunities in their core industries), leading to value creation for them. Although not all diversifying acquisitions by poor performers may be valueenhancing, there is growing evidence to suggest that under external financing constraint conditions, even poor managers in diversified firms become more efficient in their investment decisions (see Yan et al., 2010; Kuppuswamy \& Villalonga, 2016). Thus, we expect financially constrained firms to be more efficient in their diversification decisions by selecting value-enhancing diversifying (cross-industry) deals.

Finally, investors tend to anticipate the financing and other benefits of diversification and react accordingly at the announcement of M\&A deals (see Ghosh \& Jain, 2000). Consequently, acquiring firms may not need to wait until the consummation of acquisitions in order to realise the diversification benefits in the form of lower bankruptcy risk and cheaper capital. It is probable that those benefits could be realised in the pre-merger years when the firms propose and commit to undertaking diversifying acquisitions. We, therefore, expect investors to anticipate these industrial diversification benefits when firms propose to undertake cross-industry acquisitions, leading to a lesser, if not complete elimination of the ex-ante financing constraints faced by firms with leverage deviations. On this basis, we hypothesis as follows: 
Hypothesis 3: The negative effect of leverage deviation on the probability of undertaking acquisitions is mitigated when firms undertake cross-industry (diversifying) acquisitions, rather than when they make within-industry (related) acquisitions.

The geographic diversification hypothesis

The finance/international business literature suggests that acquiring domestic firms should have different risk/return implications compared to undertaking cross-border acquisitions (see Ahmed \& Elshandidy, 2018; Agyei-Boapeah, 2015; Reeb, Mansi, \& Allee, 2001). Drawing from the co-insurance effect, these studies generally suggest that a benefit of geographic diversification is lower earnings volatility as firms are able to receive cash flows from imperfectly correlated foreign markets, which, in turn, leads to a lower cost of borrowing for geographically diversified firms. Empirically, Reeb et al. (2001) report that geographic diversification is positively (negatively) related to credit rating (yield spread). Similarly, Mansi \& Reeb (2002) find that an average geographically diversified firm in their sample enjoys about a 52 basis point reduction in its cost of debt financing, which translates into greater borrowing capacity. In aggregate, these studies suggest that geographic diversification confers financing benefits on firms by reducing (improving) the bankruptcy risks (borrowing abilities) of geographically diversified corporations in comparison to purely domestic corporations.

The literature on foreign direct investment suggests further advantages of geographic diversification. Cross-border acquisitions, which often result in increased levels of geographic diversification, enable firms to expand into new geographic locations and to obtain strategic assets, advanced technologies, and new skills that cannot be obtained by purely domestic firms (see Nocke \& Yeaple, 2007). Thus, a geographically diversified firm may enjoy some competitive advantages over their domestic counterparts, which may consequently result in better performance by geographically diversified firms. Indeed, empirical research on the impact of cross-border acquisitions on the acquiring firms' shareholders' wealth suggests that cross-border acquisitions (relative to domestic acquisitions) 
enhance shareholders' wealth (see Goergen \& Renneboog, 2004). This implies that investors do recognise the potential benefits of geographic diversification associated with cross-border acquisitions and react positively upon their announcements.

However, just like industrial diversification, geographic diversification is not a guaranteed route to success. Several studies show that diversifying geographically can expose the firm to additional sources of risks such as foreign exchange risks and political risks (see Agyei-Boapeah, 2015; Krapl, 2015). Krapl (2015) finds higher systematic risks, idiosyncratic risks, and total risks for geographically diversified US firms. Within the M\&A context, Agyei-Boapeah (2015) shows that the increased risk associated with geographic diversification translates into lower borrowing for British firms that diversify geographically, especially when the firms diversify into less developed (riskier) countries. Beyond increased risks, other studies point out increased costs/complexities in international business due to geographic/cultural/psychic distance between the home nations of geographically diversified firms and their host countries (e.g., Kogut and Singh, 1988).

Taken together, geographic diversification seems to present some benefits and/or risks/costs to firms which may result in lower (or greater) financing constraint for a geographically diversified firm relative to a purely domestic firm. Unlike domestic acquisitions, when firms pursue cross-border acquisitions, they are often able to increase their levels of geographic diversification, especially when they buy targets from countries in which they previously had no operations. Therefore, if investors incorporate the risk/return implications of the proposed acquisition into their capital supply decisions, then the financing/investment constraints associated with leverage deviation may be more or less severe for those firms with leverage deviation that propose to pursue cross-border acquisitions compared to those firms pursuing domestic acquisitions. In fact, Ahmed \& Elshandidy (2018) recently show that overleveraged firms are more inclined to undertake cross-border acquisitions than domestic acquisitions since cross-border acquisitions help to reduce their bankruptcy risk as well as generate more value for 
their shareholders. Therefore, we expect net geographic diversification benefits for constrained firms, leading us to hypothesise as follows:

Hypothesis 4: The negative effect of leverage deviation on the probability of undertaking acquisitions is mitigated when firms undertake foreign (cross-border) acquisitions, rather than when they make domestic (within-country) acquisitions.

\section{Data and methods}

Method of analysis

In order to examine the link between leverage deviation and the probability of undertaking acquisitions, we follow a two-step procedure as in Uysal (2011). In the first step, we estimate the leverage deviations for firms in year $t$; and in the second step, we examine whether the leverage deviation in year $t$ affects the probability of undertaking acquisitions in the future (i.e. years $t$ to $t+5$ ) using a multivariate probit regression.

In defining future acquisitions to include deals undertaken by a firm within 5 years, we recognise that firms often make adjustments to their leverage, and thus, our sample firms that have leverage deviations in year $t$ could make alterations to their leverage and gradually eliminate the deviations within the 5 -year timeframe. Our choice of a 5 -year period is motivated by the capital structure literature which suggests that the average firm that deviates from its optimal leverage ratio takes about 4 to 5 years to return to its optimal leverage level (e.g. Lemmon et al., 2008). ${ }^{4}$

Following prior studies such as Kayhan and Titman (2007) and Uysal (2011), we define leverage deviation as the difference between a firm's actual leverage and its optimal leverage ratio. Thus, positive (negative) deviations denote overleveraging (underleveraging). While the actual leverage ratio can be

\footnotetext{
${ }^{4}$ In untabulated results, we vary our definition for future acquisitions to separately consider acquisitions undertaken in periods $t+1$ only, $t+2$ only, $t+3$ only, $t+4$ only, and $t+5$ only. All the periods (except $t+5$ ) showed a significantly negative association between leverage deviation in year $t$ and acquisition activities in those individual years. In $t+5$, the relationship was positive but insignificant. Thus, it is unlikely that our results and conclusions are significantly influenced by our time scale used in defining future acquisitions. In the interest of brevity, these results are not tabulated but are available upon request.
} 
readily computed from publicly available financial data, the optimal leverage ratio is unobservable and needs to be estimated. Based on the tradition in this field of research, we formulate Eq. (1) to estimate the optimal leverage ratio by running a cross-sectional regression of market leverage on the determinants of capital structure documented in prior studies (e.g. Rajan and Zingales, 1995; Antoniou et al., 2008). Thus, the optimal leverage ratio of firm $i$ is its fitted value of Eq. (1).

$$
\text { Leverage }_{i t}=\alpha+\phi X_{i, t-1}+\lambda+\varepsilon_{i}
$$

In Eq. (1), Leverage ${ }_{i t}$ represents the market financial leverage (defined as total debt divided by the

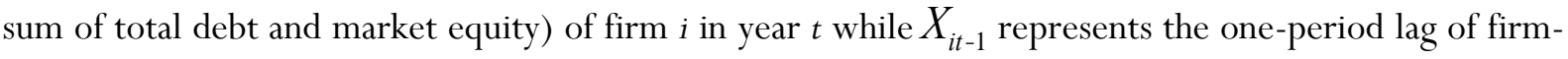
specific capital structure determinants (i.e. non-debt tax shelter, asset tangibility, research and development (R\&D) expense ratio, a dummy for missing $R \& D$ expense, return volatility, growth opportunity, firm size, profitability, stock return, past leverage levels). We define the variables as follows: (1) Non-debt tax shelter - accumulated depreciation divided by total assets; (2) Asset tangibility - net property, plant, and equipment divided by total assets; (3) R\&D expense ratio - R\&D expense divided by total assets; (4) Missing R\&D dummy - one if R\&D value is missing, otherwise zero; and (5) Return volatility - standard deviation of the monthly stock return for the year. The above definitions follow those contained in studies such as Hovakimian et al. (2004), Harford et al. (2009), Antoniou et al. (2008), and Uysal (2011). The definitions for the remaining variables (e.g. growth opportunities, size, etc.) are discussed below under the control variables for the multivariate probit regression. Eq. (1) also includes dummies to capture industry and time fixed-effect $(\lambda)$. To conserve space, we do not report the results of the optimal leverage regression.

In the second step, the baseline multivariate regression has a dummy (i.e. acquirer $=1$ and nonacquirer $=0$ ) as its dependent variable and leverage deviation (or a variant of it that reflects the direction or extent of leverage deviation) as the explanatory variable of interest. The baseline model includes several control variables selected based on guidance from the M\&A literature and our intuition. First, we control for the firms' past debt burden to indirectly capture any borrowings for recent 
investments/acquisitions. We use the average debt ratio for the past 3 years as a proxy for the past debt burden. Second, we control for firm size because large firms may find it easier to raise funds for their acquisitions. Following Rajan \& Zingales (1995), we measure firm size as the natural log of total assets. Third, since the managerial inefficiency theory (Manne, 1965) suggests that better performing firms tend to be acquirers, we include the ratio of earnings before interest, tax, depreciation and amortisation (EBITDA) to total assets to control for firm's performance/profitability. We expect this variable to proxy for managerial performance (or inefficiencies) other than those related to capital structure issues.

Fourth, Jensen's (1986) free cash flow hypothesis implies that high free-cash flow firms are more likely to make acquisitions. In line with Harford et al. (2009), cash and cash equivalent divided by total assets is included to proxy for firms' cash holdings. Fifth, we include the average annual stock return to account for two effects, i.e., the performance effect and the misvaluation effect posited by Shleifer \& Vishny (2003). Firms with high stock return may be deemed as better performing or overvalued and hence are more likely to make acquisitions, especially stock exchange deals. Sixth, Jovanovic \& Rousseau (2002) suggest that M\&As tend to be between high-Q firms and low-Q firms, which implies that high growth firms are more likely to undertake acquisitions. Thus, we control for growth opportunities by including the market-to-book ratio (see Antoniou et al., 2008). The inclusion of this variable further minimizes the possibility that our key conclusions may be driven by potential limited investment opportunities associated with extreme underleveraging or overleveraging. Seventh, we include the Herfindhal index for product and geographic diversification to account for the effect of firms' existing diversification strategies. We expect diversified (focused) firms to be more likely to undertake diversifying (related) acquisitions. Similarly, we expect firms with (without) foreign operations to be more likely to undertake cross-border (domestic) acquisitions.

Eighth, since M\&As tend to occur in waves (see Martynova \& Renneboog, 2008), we capture this effect by including the industry M\&A liquidity variable to reflect the annual volume of acquisitions in an industry. Like Uysal (2011), we measure the industry M\&A liquidity as the total value of acquisitions in 
a year within an industry divided by the annual total sales for the industry. Ninth, Uysal (2011) argues that firms in highly concentrated industries have fewer targets available for acquisition within the industry which could limit acquisition activities, particularly related acquisitions. So, we proxy for the level of industry concentration by using the sales for the constituent firms to construct industry Herfindhal index. Tenth, similar to Morck, Shleifer \& Vishny (1990), we include the target firms' industry sales growth to control for the target firms' attractiveness. ${ }^{5}$ Finally, we include year and industry dummies in order to account for changes in the macroeconomic conditions (e.g. interest rates and inflation rates) over the sample period and other industry-fixed effect beyond industry M\&A liquidity and industry concentration.

Our choice of probit regression model over other binary probability models such as logit and linear probability model is due to desirable statistical properties of probit models including producing consistent estimates of asymptotic standard errors (Powell, 1997) and to help us to directly compare our estimates to the prior US findings in Uysal (2011). Again, to aid comparison with prior studies, we report the average marginal effect for the main results.

\section{Data}

To empirically examine the relationship between firms' leverage deviation and the probability of undertaking acquisitions, we started by collecting publicly listed UK firms that are found on Datastream for the period 1996 to 2006. The pre-1996 firms were excluded because most of them did not have the data required to construct the study's variables. The cut-off date of 2006 was chosen due to the need to relate a firm's leverage deviation in year $t$ to its acquisitions occurring in years $t$ to $t+5$. For instance, for firms in 2006, our empirical procedures require us to relate their leverage deviations in 2006 to their acquisitions occurring during 2006 and 2011. Hence, it was not practicable to include firms beyond year

\footnotetext{
${ }^{5} \mathrm{We}$ are grateful to an anonymous reviewer for this suggestion. However, information on target firms is only available for those firms that made acquisitions. For non-acquirers, we assume their counterfactual targets to be in the same industry as them, and therefore use their industry data in the target's industry sales growth computation. Excluding this variable does not change our main conclusions.
} 
2006 since all their required future acquisitions (5 years forward) were unobservable at the time of data collection.

We only keep those firms in our sample for which there is available data to calculate leverage deviation and all other variables needed for the multivariate probit regression. Following the extant literature (e.g. Agyei-Boapeah, 2015; Uysal, 2011; Kayhan and Titman, 2007), we also exclude firms from the financial and regulated utilities industries. The final sample consists of 9,749 observations for 1,845 unique firms. The distribution of the sample across industry and years are displayed in Panel A of Table 1. The sample is almost evenly distributed across the years but not across industries.

\section{[INSERT TABLE 1]}

Since our primary aim is to relate leverage deviations to firms' M\&A activities, we also obtained data on all completed M\&As by our sample firms during 1996 to 2011 from Thomson Financials' Securities Data Company's (SDC) Merger and Acquisitions database. There were 9,115 completed M\&As valued at over $£ 800$ trillion made by our sample firms. Panel B of Table 1 contains the characteristics of our M\&A sample. The deals are almost evenly split between within-industry (52\%) and cross-industry deals $(48 \%)$. The within-industry deals are on average larger than the cross-industry deals (£129m vs. $£ 43 m)$. Consistent with Doukas \& Kan (2008), we define acquisitions to be withinindustry (cross-industry) when the acquirer and the target firm share the same (different) 2-digit SIC code.

When the deals are classified by their potential to impact the acquirer's geographic diversification, we find the domestic deals (57\%) to outnumber the cross-border deals (43\%). But the average crossborder deal is bigger than the average domestic deal (£145m vs. $£ 45 \mathrm{~m})$. We define domestic (crossborder) deals to include those acquisitions which have the acquirer and the target firm domiciled in the same (different) countries.

Sample classifications 
In order to implement our probit regressions to examine the impact of leverage deviation on acquisition probability, we utilise the M\&A data to segregate our 9,749 observations into acquirers and nonacquirers. We define acquirers to include firms in year $t$ that are observed to have made at least one acquisition during the years $t$ to $t+5$. In contrast, firms in year $t$ that had no acquisitions during $t$ to $t+5$ were deemed to be non-acquirers. Based on this definition, over half $(60 \%)$ of the firms in our sample was classified as acquirers, with the remaining $40 \%$ classified as non-acquirers.

We also distinguish between firms that substantially deviate from their optimal leverage ratios (extreme deviation firms) and those that are close to the optimal leverage (moderate deviation firms). Following Uysal (2011), this segregation is done by utilising the estimated leverage deviation variable to divide our 9,749 firms into quartiles. The first and fourth quartile (Q1 and Q4) firms are termed extreme deviation firms, and it is this group of firms that we expect to be sub-optimal and should thus experience higher levels of financing/investment constraints. The extreme deviants are either extremely underleveraged (Q1) or extremely overleveraged (Q4). Since the second and third quartile (Q2 and Q3) firms are relatively closer to the optimal leverage, we classified them as moderate deviation firms, and they are not expected to face substantial risk of financial/investment constraints.

Overall, our empirical test of the link between leverage deviation and acquisition probability is implemented by employing our subsamples of acquirers and non-acquirers, on the one hand, and the subsamples of extreme and moderate deviation firms, on the other hand, in a multivariate probit regression framework.

\section{Results}

Table 2 (Panel A) reports descriptive statistics for the study's variables for the full sample and also across the acquirer and non-acquirer subsamples. To limit the effect of outliers, we have winzorised all the variables, (except leverage deviation) at the bottom and top $1 \%$. We did not winzorise leverage 
deviation because the variables used in deriving it were first winzorised. More so, it is the extreme values of the leverage deviation variable that are of particular interest to this study.

According to our full data, the standard deviation for leverage deviation is 0.113 and the highest underleveraged (overleveraged) firm is about 75\% (73\%) below (above) its optimal leverage. These statistics suggest a substantial variation in the leverage ratios of our sample firms around their optimal leverage ratios. Further, relative to the acquirers, the non-acquirers exhibit characteristics that suggest that they may find it difficult to access capital for their investment projects. Specifically, the nonacquirers have significantly higher past debt burden (0.21 vs. 0.18$)$, lower levels of growth prospects (1.95 vs. 2.13$)$, profitability (0.018 vs. 0.080$)$, stock return (0.001 vs. 009$)$, size (10.7 vs. 11.5$)$, and foreign sales (0.20 vs. 0.27). In Panel B of Table 2, the correlation coefficients are low (all below 0.41), indicating that multicolinearity may not pose any serious limitations on our multivariate regressions.

\section{[INSERT TABLE 2]}

Table 3 displays the results for the test of Hypothesis 1 which predicts a negative association between leverage deviation and acquisition probability. As shown in Model 1, the leverage deviation (continuous) variable is negative and statistically significant ( $\beta=-0.094, p=0.049$ ), indicating that a unit deviation from a firm's optimal leverage is associated with an average of $9.4 \%$ lower probability of completing an acquisition in the future (i.e. $t$ to $t+5$ ). Though the result in Model 1 supports Hypothesis 1, it does not adequately show how extreme leverage deviation relates to firms' acquisition probability. Accordingly, in Models 2-4, we capture the collective extreme deviation (Q1 and Q4) effect as well as the individual extremely underleveraged (Q1) and overleveraged (Q4) effects relative to moderate deviation firms (Q2 and Q3). This is implemented by modifying our baseline model to include the following interaction variables in the relevant Models: (1) an interaction term between leverage deviation and a dummy for extreme deviation firms (Model 2); (2) an interaction term between leverage deviation and a dummy for extremely underleveraged firms (Model 3); and (3) an interaction term between leverage deviation and a dummy for extremely overleveraged firms (Model 4). 
The results in Model 2 of Table 3 indicate that the interaction variable for leverage deviation and the dummy for extreme deviations is negative and significant $(\beta=-0.790, p=0.005)$, implying a significantly lower chance of completing acquisitions when firms maintain leverage levels that substantially depart from their optimal leverage ratios. The coefficient for the extreme deviation dummy suggests that extreme deviant firms generally have about 2.9\% significantly lower probability of making an acquisition. Also, the coefficient for leverage deviation which represents the average effect of the other (moderate deviation) firms is positive and significant. This implies that relative to the extreme deviant firms, the leverage deviation of moderate deviants is positively associated with acquisition likelihood.

\section{[INSERT TABLE 3]}

Further, we recognise that extreme deviations from the optimal leverage may take one of two forms, i.e., firms may stay under (underleverage) or go beyond the optimal level (overleverage). Moreover, we have argued in Section 2 that both extreme under- and over-leveraging are expected to reduce acquisition propensity. Therefore, we test our argument/assumption in Models 3 and 4, by splitting the extreme deviation effect into underleverage (Q1) and overleverage (Q4) effects. Consistent with our conjecture, the results show that both extreme underleveraging and extreme overleveraging have a negative and statistically significant effect on corporate acquisition probability $(\beta=-0.523$, $p=0.097$, in Model 3; $\beta=-0.950, p=0.002$, in Model 4).

The results for the test of the mediating roles of internal capabilities and corporate diversification on the link between leverage deviation and acquisition probability (Hypotheses 2-4) are presented in Table 4. As argued earlier in Section 2, the resource-based view suggests that firms with superior internal (intangible) resources, in the form of technological, organisational, and managerial capabilities, may be more appealing to investors, and hence can neutralise any potential negative effect of leverage deviation on their ability to complete acquisitions (Hypothesis 2). Testing Hypothesis 2 requires an empirical proxy for firm capabilities. A careful assessment of the bundle of internal firm capabilities in 
Barney (1991) and Teece et al. (1997) suggests that market-based performance measures such as Tobin's q or stock returns which capture investors' assessments of firms' intangible attributes provide the best empirical estimates for firms' internal capabilities. ${ }^{6}$ Thus, we use Tobin's q (measure of growth prospects) as our main measure of the envelopment of the myriad of organisational capabilities residing inside the firm.

The results reported in Models 1 and 2 of Table 4 provide support for Hypothesis 2. Specifically, the effect of leverage deviation on acquisition probability becomes positive but statistically insignificant for high growth firms $(\beta=0.033, p=0.764$ in Model 1$)$, while it remains negative and statistically significant for low growth firms $(\beta=-0.185, p=0.001$ in Model 2). In untabulated results, we also utilise two alternative proxies (average stock return and research and development expenditure) for robustness testing and the results remain qualitatively similar. Also, employing an alternative model involving an interaction variable between leverage deviation and the measures of internal capabilities, as well as, specifications that exclude growth opportunities from the list of regressors yielded similar conclusions. We therefore conclude that the presence of valuable firm-specific internal capabilities (as captured by growth prospects) moderates the negative impact of leverage deviation on acquisition probability.

On the moderating impact of diversification, we have previously argued that the negative link between leverage deviation and acquisition probability increases or decreases according to the type/nature of acquisitions undertaken by a firm. In particular, Hypotheses 3 and 4 posit that the benefits of corporate diversification may reduce the ex-ante financial/investment constraints associated with leverage deviation. Thus, there should be a lesser (or greater) effect of leverage deviation on acquisition probability when firms undertake diversifying (cross-industry and cross-border) acquisitions

\footnotetext{
${ }^{6}$ Barney (1991) defines firms' internal resources/capabilities to include all resources and strengths (such as assets, capabilities, organisational processes, management skills and innovation, firm attributes, information, and knowledge, etc.) that the firm can use to conceive of and implement its strategies. Teece et al (1997) also note that firms' resources that are capable of generating competitive advantage and value-creating strategies consist of a portfolio of difficult-to-trade knowledge assets which include technological, organisational, and managerial processes residing in the firm.
} 
rather than non-diversifying (within-industry and domestic) acquisitions. In conducting these tests, the baseline multivariate probit regression is slightly modified. The dependent variable reflects the specific type of acquisition (i.e. cross-industry, within-industry, cross-border, or domestic) being modelled. For example, in modelling the probability of undertaking a cross-industry acquisition, the dependent variable is one if a firm makes a cross-industry acquisition, and zero otherwise. The independent variable of interest in this set of analysis is the continuous variable (not a dummy) for leverage deviation.

The results reported in Models 3 and 4 of Table 4 show that while leverage deviation has a positive but statistically insignificant impact on cross-industry acquisitions ( $\beta=0.009, p=0.856$, in Model 3), its impact on within-industry acquisitions is significantly negative $(\beta=-0.140, p=0.005$, in Model 4$)$. The conclusion remains unchanged when we repeat the tests for the subsample of extreme deviation firms and for our extremely underleveraged and overleveraged subsamples. In the interest of brevity, these latter results are untabulated. Overall, the results reported in Models 3-4 provide strong evidence in support of Hypothesis 3, and suggest that firms that deviate from their optimal leverage have a better chance of completing a cross-industry acquisition compared to a within-industry acquisition.

\section{[INSERT TABLE 4]}

Turning to the role of geographic diversification, the results displayed in Models 5-6 of Table 4 suggest that the negative impact of leverage deviation on acquisition probability is statistically insignificant when firms commit to undertake cross-border (foreign) acquisitions but remains significant in domestic (within-country) acquisitions. While the negative link between leverage deviation and acquisition probability is only -0.009 with p-value of 0.864 in cross-border acquisitions (Model 5), the value is higher, $-0.117(p=0.017)$, in domestic acquisitions (Model 6). These results are consistent with Hypothesis 4 and suggest that firms that deviate from their optimal leverage ratios have better acquisition prospects when they commit to undertake cross-border acquisitions than to domestic acquisitions. 
Finally, the results on the control variables help to eliminate other potential explanations for our key findings. A possible concern about our finding of lower acquisition probability among extreme deviation (extremely under-and over-leveraged) firms is that they may not have the incentive to make acquisitions possibly because they have made recent investments or do not have sufficient investment opportunities. Since most huge corporate investments rely on debt (Harford et al., 2009), these concerns are minimized by specifically controlling for firms' past debt burden. As the results indicate, firms with high past debt burden (likely to represent those with recent capital investments) are less likely to make acquisitions in the immediate future. More so, past investments are likely to reduce future growth opportunities. Therefore, we control for the growth opportunities of the firms. As expected, we find firms with higher growth opportunities (lesser past investments) to be more likely to make acquisitions. Further, acquisitions are more likely among larger firms and those with higher international business experience, profitability, and stock return, as well as those targeting firms in growth industries. However, the finding of lower acquisition propensity for high cash-flow firms is inconsistent with the free cash flow hypothesis (agency theory). Finally, the level of product diversification within a firm and the level of concentration within an industry as well as the frequency of acquisitions in an industry do not seem to significantly influence acquisition propensity. Most of the time and industry dummies were statistically significant but are unreported to conserve space.

\section{Robustness checks}

This section conducts a number of robustness tests. First, we test whether the history of acquisitions and/or past acquisition experience affects our results. We conduct this analysis by repeating the pooled cross-sectional probit regression (CSA) for only our subsample of acquirers that made more than one acquisitions during $t$ and $t+5$ (i.e. multiple acquirers). As shown in Model 1 of Table 5, the significant negative association between leverage deviation and acquisition probability remains ( $\beta=-0.128$, 
$p=0.032$ ). Thus, our conclusions are not affected by the history of acquisitions and/or past acquisition experience of the acquiring firms.

\section{[INSERT TABLE 5]}

Second, we assess the possible impact of endogeneity on our results by implementing generalised least squares (GLS) random-effect (panel) regressions to eliminate unobserved firm heterogeneity (e.g. managerial ability). The panel data models do not easily allow us to relate the leverage deviation in $t$ to all the acquisitions occurring in $t$ to $t+5$, so we match a firm's leverage deviation against its acquisitions in that year. Consequently, the M\&A data for the panel data model only covers the period 1996-2006 (but not 1996-2011). Further, the panel data models implemented in STATA 14 does not allow us to report the marginal effects for the coefficients, so the original parameter estimates are reported in Model 2 of Table 5. The coefficients cannot therefore be directly interpreted as probabilities. The panel data results in Model 2 ( $\beta=-0.457, p=0.007$ ) remain qualitatively similar to our earlier cross-sectional probit results.

In addition, we conduct analysis of the key issues by digging deeper into our subsample of acquirers. We regress the number of acquisitions made by a firm on its leverage deviation and the set of control variables. From Model 3 of Table 5, we observe a significantly negative relationship between the number of acquisitions made and leverage deviation $(\beta=-0.208, p=0.006)$, indicating that deviations from the optimal leverage ratio does not only limit the propensity to undertake acquisitions, but also constrains the number of acquisitions that firms are able to make in a period. Since these results are not based on our baseline probit models, we report the results for the internal capabilities, industrial and geographic diversification hypotheses. As can be seen in Models 4-5, leverage deviation significantly constrains the number of acquisitions in both high-growth firms ( $\beta=-0.476, p=0.005$, in Model 4) and low-growth firms ( $\beta=-0.235, p=0.007$, in Model 5). This suggests that firm' internal capabilities do not moderate the effect of leverage deviation on the number of acquisitions made. 
However, in Models 6-9, leverage deviation has no significant effect on the number of crossindustry $(\beta=0.014, p=0.928$, in Model 6) and cross-border $(\beta=-0.028, p=0.865$, in Model 8) acquisitions made. However, the effect of leverage deviation on the number of acquisitions made is negative and significant in both within-industry $(\beta=-0.339, p=0.004$, in Model 7) and domestic $(\beta=$ 0.269, $p=0.008$, in Model 9) acquisitions. It seems the industrial and geographic diversification benefits extend to the number of acquisitions made by acquirers. In sum, these poisson regression results, based on the number of acquisitions (a count dependent variable), are qualitatively similar to those derived from the probit models (based on a binary dependent variable), except for our internal capabilities hypothesis (H2).

Finally, in untabulated results, we find very mild evidence to suggest that the benefits of diversification in mitigating the negative effect of leverage deviation on acquisition likelihood may be non-monotonic. Specifically, the effect of leverage deviation on acquisition propensity is insignificantly positive (but often negative) when firms make single (multiple) diversifying acquisitions. This suggests that beyond a single diversifying acquisition, the benefits associated with diversifying acquisitions weaken. Overall, our main finding of leverage deviation restricting acquisition activities (incidence and frequency), especially non-diversifying acquisitions (within-industry and domestic deals) is robust across a raft of economic specifications and subsamples.

\section{Discussion}

Taken together, the empirical findings presented in this article provide strong evidence that corporate deviations from the optimal leverage ratio are associated with lower acquisition probability. This is consistent with the findings in the US study by Uysal (2011). Given the similarity of the financial/economic systems between the UK and US, the findings imply that investors in a market economy do punish corporate inefficiencies by withholding financing from suboptimal firms. However, our finding compared with that of Uysal (2011) indicates that the average leverage deviation effect on 
acquisition probability is stronger in the UK (-0.094) than in the US (-0.052). This suggests that a UK firm that deviates from its optimal leverage is about 1.8 times less likely to make an acquisition compared to its US counterpart.

The higher leverage deviation effect for our UK sample may simply reflect the institutional difference between the UK and the US in terms of access to credit and financial market development. The UK, compared with the US, has a relatively smaller and illiquid financial market. In particular, the more developed bonds markets in the US seems to give US firms greater access to public bond (see Mittoo \& Zhang, 2010), and in turn results in lower borrowing costs and reduced financing constraints for US deviant firms. Altogether, deviations from leverage deviation is costly for both US and UK firms, but the relatively smaller and less liquid financial market in the UK make financially-constrained UK firms appear to face a more serious financing problem than their US counterparts with access to a wider domestic financial market. This suggests that the size and efficiency of the national financial markets may influence the levels of financing constraints (at the firm-level) associated with leverage deviations. The difference in the leverage deviation effect may also be due to the difference in the research design of the two studies. As noted earlier, the prior study relates a firm's leverage deviation to its acquisitions during an 18-year period, whereas the present study relates a firm's leverage deviation in year $t$ to its acquisitions within a shorter time frame ( $t$ to $t+5)$. Thus, our sample firms don't seem to have sufficient time to undo their leverage deviations prior to undertaking acquisitions, which then makes the constraints associated with their leverage deviation more binding on them.

The study's finding of a significant (though weak) and negative association between extreme underleveraging and acquisition probability is inconsistent with the view that extreme underleveraging may represent unused debt capacity (DeAngelo et al., 2011). Our findings imply that any form of extreme deviation (whether underleverage or overleverage) may be associated with a reduced ability to undertake acquisitions. Our results also confirm the findings in van Binsbergen et al. (2010) that the costs associated with overleveraging is far greater than that of underleveraging. Extreme overleveraging 
seems to almost certainly make it impossible for firms to undertake acquisitions in the immediate future (effect of $-95.0 \%$ ), whereas extreme underleveraging halves the chances of undertaking an acquisition (effect of $-52.3 \%$ ). Overall, the results imply that the optimal leverage ratio is important because deviating substantially from it restricts firms' ability to undertake future investments.

The paper also finds evidence to suggest that the cost of leverage deviation in terms of limiting the ability to complete acquisitions is not symmetric across all firms. In fact, firms that have valuable organisation resources such as superior managerial and technological capabilities seem to be able to neutralise the cost of leverage deviation. This supports the resource-based view of the firm, which suggests that some firm-specific capabilities could act as a source of competitive advantage and valuecreation for firms (Barney, 1991; Teece et al., 1997). These findings also imply that investors in financing M\&As do indeed consider the value-creation potential of those deals through the resources/capabilities residing inside the acquiring firm.

Another key empirical evidence presented in this paper is that corporate diversification, both industrial and geographic, moderates the financial/investment constraints that may be associated with deviations from optimal leverage ratios. This supports the view that corporate diversification may have more financial benefits than costs (Lewellen, 1971; Hann et al., 2013), especially for financially constrained firms (Kuppuswamy \& Villalonga, 2016). First, we show that the financing/investment constraints associated with leverage deviation disappear when managers choose cross-industry deals, but not within-industry deals. Given that cross-industry deals are more likely to lead to increased levels of product diversification, our results support the recent findings in Yan et al. (2010) and Kuppuswamy \& Villalonga (2016), suggesting that industrial diversification results in net benefits for financially constrained firms. The specific reasons which possibly make cross-industry acquisitions advantageous include their potential to diversify acquirers' cash flows, and the development of new internal capital markets or improvements in the efficiency of existing internal capital markets, among others. Similarly, our results support the view that increasing levels of geographic diversification through M\&As may be 
associated with net benefits (Ahmed \& Elshandidy, 2018), partly emanating from improved stability of cash flow, higher market share, and competitive advantages from obtaining strategic assets, advanced technologies, and new skills by expanding into new geographic locations (see Nocke \& Yeaple, 2007).

\section{Conclusions and managerial implications}

This study contributes to the literature on the link between capital structure and investment decisions by documenting a negative association between a firm's deviations from its optimal leverage ratio and its ability to initiate and successfully complete acquisitions. This suggests that deviation from the optimal leverage makes it difficult to raise further debt capital to finance subsequent corporate investments, possibly because the firms with leverage deviation are viewed by investors to be either too risky or suboptimal. We also find the association between leverage deviation and the probability of undertaking an acquisition among our UK sample to be almost twice larger than that reported in the prior US study by Uysal (2011). This suggests that the cost for firms with leverage deviation (in terms of the difficulty in obtaining financing and the subsequent forgone acquisition deals) is much higher for UK firms than was previously suggested in the US literature. Perhaps, the relatively smaller bonds market (in comparison with that of the US bond markets) in the UK worsens the higher cost of capital problem faced by UK firms with leverage deviations. Another implication of the results is that it is not sufficient for firms to have optimal leverage ratios, but corporate managers must strive to keep their leverage levels closer to the optimal leverage. Thus, the results provide evidence in support of the existence and relevance of the trade-off theory of capital structure. Moreover, if deviations from the optimal leverage are reflective of inefficient (sub-optimal) managerial actions, then the results are consistent with the managerial inefficiency theory of M\&A. That is, managers of firms with sub-optimal leverage policies are unlikely to become acquirers in acquisition deals.

More importantly, we show that firms that have deviated from their optimal leverage ratios face different financing/investment constraints depending on their existing levels of firm-specific internal 
capabilities and the type of acquisitions they propose to undertake. The firms with higher internal capabilities do not seem to face significant constraints in terms of the incidence (but not the volume) of acquisitions even when they deviate from the optimal leverage. Similarly, those firms with leverage deviations that pursue cross-industry acquisitions seem to face lower constraints relative to those that undertake within-industry acquisitions. These results imply that the anticipated benefits such as sustained competitive advantages associated with internal organisational capabilities, as well as, the improved cash flow stability associated with corporate industrial diversification tend to moderate the financing/investment constraints associated with leverage deviation. Furthermore, we provide evidence to suggest that geographic diversification may also reduce the financial/investment constraints associated with leverage deviation. We show that firms with leverage deviation generally face no financing/investment constraints when they propose cross-border (foreign) deals, but do face significant constraints when they propose domestic (within-country) deals. This finding is consistent with the view that international business/diversification has financial benefits through achieving greater market share and new skills and resources from new foreign locations.

Taken together, the empirical evidence in this paper suggests that there are some benefits of firms' internal capabilities and corporate diversification that are anticipated by suppliers of capital when a deviant firm (possibly with some internal non-financial capabilities) commits to undertake an investment which has the potential to diversify its cash flows across other industries or countries. Therefore, managers of firms with leverage deviation may be more successful in overcoming the financing/investment constraints faced by their firms when they embark on diversifying (cross-industry and cross-border) investments than non-diversifying (within-industry and domestic) investments. Additionally, the financing/investment constraints may be mitigated if deviant firms are able to enhance their internal (intangible) resources/capabilities.

Although this paper contributes to the literature by suggesting that the diversification characteristics of a proposed acquisition deal may influence the financing/investment constraints associated with 
leverage deviation, it does not consider how the pre-acquisition level of diversification of the acquiring firm itself could influence the financing/investment constraints related to leverage deviation. Future studies can further inquire into this matter. It may also be interesting to investigate the link between leverage deviation and investments in emerging economies with less developed capital markets. Further, our results are based on a sample of UK firms and thus its generalizability to other contexts may be limited. A study involving an international sample and enabling a cross-country analysis will be a step in the right direction. Finally, our results should be interpreted with caution because inasmuch we controlled for several factors in our empirical model, data limitations did not permit us to include proxy variables for corporate governance, for example, which may influence a firm's propensity to acquire.

\section{References}

Agyei-Boapeah, H. 2015. Cross-border acquisitions and financial leverage of UK acquirers. Accounting Forum 39(2): 97108.

Ahmed, Y. and Elshandidy, T., 2018. Why do over-deviated firms from target leverage undertake foreign acquisitions? International Business Review 27(2): 309-327.

Antoniou, A., Guney, Y. and Paudyal, K., 2008. The determinants of Capital Structure: Capital Market-Oriented versus Bank-Oriented Institutions. Journal of Financial and Quantitative Analysis, Vol. 43(1): 59-92.

Barney, J., 1991. Firm resources and sustained competitive advantage. Journal of Management, 17(1), pp.99-120.

Barton, S.L. and Gordon, P.J., 1988. Corporate Strategy and Capital Structure. Strategic Management Journal, 9(6): 623632.

DeAngelo, H., DeAngelo, L., and Whited, T.M., 2011. Capital structure dynamics and transitory debt. Journal of Financial Economics, 99(2): 235-261.

Doukas, J.A., and Kan, O.B., 2008. Investment decisions and internal capital markets: Evidence from acquisitions. Journal of Banking and Finance, 32(8): 1484-1498.

Elsas, R., and Florysiak, D., 2011. Heterogeneity in the Speed of Adjustment towards Target Leverage. International Review of Finance, 11(2): 181-211.

Erdorf, S., Hartmann-Wendels, T., Heinrichs, N., and Matz, M. 2013. Corporate diversification and firm value: A survey of recent literature. Financial Markets and Portfolio Management, 27(2): 187-215.

Erel, I., Liao, R. C. \& Weisbach, M. S., 2012. Determinants of cross-border mergers and acquisitions. Journal of Finance, 67(3): 1045-1082.

Eschen, E., and Bresser, R.K.F., 2005. Closing resource gap: towards a resource-based theory of advantageous mergers and acquisitions. European Management Review, 2: 167-178.

Fischer, E.O., Heinkel, R., and Zechner, J., 1989. Dynamic Capital Structure Choice: Theory and Tests. The Journal of Finance, 44(1): 19-40.

Ghosh, A. and Jain, P.C., 2000. Financial leverage changes associated with corporate Mergers. Journal of Corporate Finance, 6, 377-402.

Goergen, M., and Renneboog, L., 2004. Shareholder Wealth Effects of European Domestic and Cross-border Takeover Bids. European Financial Management, 10(1): 9-45.

Hann, R.N., Ogneva, M. and Ozbas, O., 2013. Corporate Diversification and the Cost of Capital. The Journal of Finance, 68(5): 1961-1999.

Harford, J., Klasa, S. and Walcott, N., 2009. Do firms have leverage targets? Evidence from acquisitions. Journal of Financial Economics, 93(1): 1-14.

Hovakimian, A., Opler, T. and Titman, S., 2001. The Debt-Equity Choice. Journal of Financial and Quantitative Analysis, 36(1): 1 . 
Jensen, M.C., 1986. Agency Costs of Free Cash Flow, Corporate Finance, and Takeovers. The American Economic Review, 76(2): 323-329.

Jovanovic, B. and Rousseau, P.L., 2002. The Q-Theory of Mergers. The American Economic Review, 92(2): 198-204.

Kayhan, A. and Titman, S., 2007. Firms' histories and their capital structures. Journal of Financial Economics, 83(1): 1-32.

Kogut, B., and Singh, H., 1988. The effect of national culture on the choice of entry mode. Journal of International Business Studies, 19(3), 411-432.

Krapl, A.A., 2015. Corporate international diversification and risk. International Review of Financial Analysis, 37: 1-13.

Kuppswamy, V., and Villalonga, B., 2016. Does diversification create value in the presence of external financial constraints? Evidence from the 2007-2009 financial crisis. Management Science, 62(4): 905-923.

Lang, L.H.P., and Stulz, R.M., 1994. Tobin's q, corporate diversification, and firm performance. Journal of Political Economy 102(6): 1248-1280.

Lee, I., Lochhead, S., Ritter, J., and Zhao, Q., 1996. The cost of raising capital. Journal of Financial Research, 19(1): 5974.

Lemmon, M.L., Roberts, M.R., and Zender, J.F., 2008. Back to the Beginning: Persistence and the Cross-Section of Corporate Capital Structure. The Journal of Finance, 63(4): 1575-1608.

Lewellen, W.G., 1971. A Pure Financial Rationale for the Conglomerate Merger. The Journal of Finance, 26(2): $521-537$.

Manne, H., G., 1965. Mergers and the market for corporate control. Journal of Political Economy, 73(2): 110-120.

Mansi, S.A. and Reeb, D.M., 2002. Corporate International Activity and Debt Financing. Journal of International Business Studies, 33(1): 129-147.

Martynova, M., and Renneboog, L., 2008. A century of corporate takeovers: What have we learned and where do we stand? Journal of Banking \& Finance, 32(10): 2148-2177.

Martynova, M., and Renneboog, L., 2009. What determines the financing decision in corporate takeovers: Cost of capital, agency problems, or the means of payment? Journal of Corporate Finance, 15(3): 290-315.

Mittoo, U.R. and Zhang, Z., 2010. Bond market access, credit quality, and capital structure: Canadian evidence. The Financial Review, 45(3): 579-602.

Montgomery, C.A., and Singh, H., 1984. Diversification strategy and systematic risk. Strategic Management Journal, 5 : 181-191.

Morck, R., Shleifer, A., and Vishny, R.W., 1990. Do Managerial Objectives Drive Bad Acquisitions? The Journal of Finance, 45(1): 31-48.

Myers, S.C., 1977. Determinants of corporate borrowing. Journal of Financial Economics, 5(2): 147-175.

Nocke, V. and Yeaple, S., 2007. Cross-border mergers and acquisitions vs. Greenfield foreign direct investment: The role of firm heterogeneity. Journal of International Economics, 72(2): 336-365.

Powell, R.G., 1997. Modelling Takeover Likelihood. Journal of Business Finance \& Accounting, 24(7-8): 1009-1030.

Rajan, R.G. and Zingales, L., 1995. What Do We Know about Capital Structure? Some Evidence from International Data. The Journal of Finance, 50(5): 1421-1460.

Reeb, D.M., Mansi, S.A. and Allee, J.M., 2001. Firm Internationalization and the Cost of Debt Financing: Evidence from Non-Provisional Publicly Traded Debt. The Journal of Financial and Quantitative Analysis, 36(3): 395-414.

Roll, R., 1986. The Hubris Hypothesis of Corporate Takeovers. The Journal of Business, 59(2): 197-216.

Shleifer, A., and Vishny, R.W., 2003. Stock market driven acquisitions. Journal of Financial Economics, 70(3): 295-311.

Singhal, R. and Zhu, Y., 2013. Bankruptcy risk, costs and corporate diversification. Journal of Banking \& Finance, 37(5): 1475-1489.

Stigler, G.J., 1964. A theory of oligopoly. Journal of Political Economy, 72(1): 44-61.

Teece, D.J., Pisano, G., and Shuen, A., 1997. Dynamic Capabilities and Strategic Management. Strategic Management Journal, Vol. 18(7), pp.509-533.

United Nations Conference on Trade and Investment (UNCTAD), 2000. World Investment Report 2000. New York and Geneva: United Nations.

Uysal, V.B., 2011. Deviation from the target capital structure and acquisition choices. Journal of Financial Economics, 102(3): 602-620.

Van Binsbergen, J.H., Graham, J.R. and Yang, J., 2010. The Cost of Debt. The Journal of Finance, 65(6): $2089-2136$.

Yan, A., Yang, Z., and Jiao, J., 2010. Conglomerate investments under various capital market conditions. Journal of Banking and Finance, 34(1): 103-115. 
Table 1 - PANEL A: Sample firms by year and industry

\begin{tabular}{|c|c|c|c|c|c|c|c|c|c|c|c|c|}
\hline Industry/Year & 1996 & 1997 & 1998 & 1999 & 2000 & 2001 & 2002 & 2003 & 2004 & 2005 & 2006 & Total \\
\hline Automobiles \& Parts & 9 & 8 & 9 & 8 & 6 & 7 & 6 & 6 & 8 & 8 & 5 & 80 \\
\hline Basic Resources & 21 & 22 & 20 & 18 & 18 & 17 & 19 & 20 & 21 & 27 & 29 & 232 \\
\hline Chemicals & 31 & 28 & 24 & 22 & 17 & 17 & 16 & 16 & 16 & 14 & 14 & 215 \\
\hline Construction \& Materials & 53 & 56 & 51 & 43 & 41 & 37 & 36 & 35 & 32 & 30 & 28 & 442 \\
\hline Food \& Beverage & 53 & 48 & 47 & 45 & 39 & 35 & 35 & 33 & 32 & 29 & 29 & 425 \\
\hline Health Care & 29 & 35 & 38 & 49 & 48 & 52 & 58 & 59 & 56 & 60 & 74 & 558 \\
\hline Industrial Goods \& Services & 282 & 272 & 251 & 253 & 238 & 247 & 245 & 260 & 249 & 243 & 258 & 2798 \\
\hline Media & 61 & 60 & 51 & 50 & 48 & 62 & 78 & 75 & 76 & 71 & 72 & 704 \\
\hline Oil \& Gas & 19 & 19 & 18 & 23 & 23 & 26 & 27 & 34 & 33 & 33 & 41 & 296 \\
\hline Personal \& Household Goods & 117 & 112 & 101 & 88 & 84 & 81 & 77 & 73 & 64 & 61 & 59 & 917 \\
\hline Retail & 87 & 85 & 84 & 88 & 85 & 80 & 71 & 69 & 67 & 65 & 62 & 843 \\
\hline Technology & 64 & 64 & 65 & 86 & 97 & 143 & 165 & 156 & 141 & 148 & 158 & 1287 \\
\hline Telecommunications & 4 & 7 & 10 & 10 & 9 & 16 & 13 & 12 & 12 & 15 & 17 & 125 \\
\hline Travel \& Leisure & 59 & 64 & 72 & 78 & 77 & 86 & 89 & 82 & 81 & 70 & 69 & 827 \\
\hline Total & 889 & 880 & 841 & 861 & 830 & 906 & 935 & 930 & 888 & 874 & 915 & 9749 \\
\hline \multicolumn{13}{|c|}{ PANEL B: M\&A distribution by types of acquisitions } \\
\hline Type of deal & \multicolumn{2}{|c|}{ All deals } & \multicolumn{3}{|c|}{ Cross-industry deals } & \multicolumn{2}{|c|}{ Within-industry deals } & \multicolumn{3}{|c|}{ Cross-border deals } & \multicolumn{2}{|c|}{ Domestic deals } \\
\hline Number of acquisitions & \multicolumn{2}{|c|}{9,115} & \multicolumn{3}{|c|}{$4 \quad 4,371$} & \multicolumn{2}{|c|}{4,744} & \multicolumn{3}{|c|}{3,907} & \multicolumn{2}{|c|}{5,208} \\
\hline Percentage of acquisitions & \multicolumn{2}{|c|}{$100 \%$} & \multicolumn{3}{|c|}{$48 \%$} & \multicolumn{2}{|c|}{$52 \%$} & \multicolumn{3}{|c|}{$43 \%$} & \multicolumn{2}{|c|}{$57 \%$} \\
\hline Total value of acquisitions (£’mil) & \multicolumn{2}{|c|}{$802,227.35$} & \multicolumn{3}{|c|}{$188,836.95$} & \multicolumn{2}{|c|}{$613,390.40$} & \multicolumn{3}{|c|}{$568,239.76$} & \multicolumn{2}{|c|}{$233,987.58$} \\
\hline Average value of acquisition (£’mil) & \multicolumn{2}{|c|}{88.01} & \multicolumn{3}{|c|}{43.20} & \multicolumn{2}{|c|}{129.30} & \multicolumn{3}{|c|}{145.44} & \multicolumn{2}{|c|}{44.93} \\
\hline
\end{tabular}

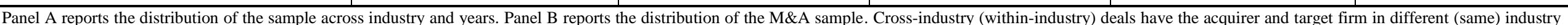
as defined by the 2-digit SIC codes. Cross-border (domestic) deals have the acquirer and the target firm domiciled in different (same) countries. 
Table 2 - PANEL A: Summary statistics for full sample and sub-samples

\begin{tabular}{|c|c|c|c|c|c|c|c|c|c|c|c|c|}
\hline \multirow{2}{*}{ Variables/Sample firms } & \multicolumn{4}{|c|}{ All firms $($ Obs. $=9,749)$} & \multicolumn{4}{|c|}{ Acquirers $($ Obs. $=5,858)$} & \multicolumn{4}{|c|}{ Non-acquirers $($ Obs. $=\mathbf{3 , 8 9 1})$} \\
\hline & Mean & Std. dev. & Min. & Max. & Mean & Std. dev. & Min. & Max. & Mean & Std. dev. & Min. & Max. \\
\hline \multicolumn{13}{|l|}{ Independent variables } \\
\hline Leverage deviation & 0.000 & 0.113 & -0.745 & 0.727 & -0.004 & 0.106 & -0.745 & 0.659 & 0.006 & 0.123 & -0.680 & 0.727 \\
\hline Moderate deviation & -0.007 & 0.020 & -0.055 & 0.044 & -0.007 & 0.020 & -0.055 & 0.044 & -0.006 & 0.019 & -0.055 & 0.043 \\
\hline Extreme deviation & 0.006 & 0.111 & -0.745 & 0.727 & 0.002 & 0.104 & -0.745 & 0.659 & 0.012 & 0.121 & -0.680 & 0.727 \\
\hline Extreme underleverage & -0.029 & 0.065 & -0.745 & 0.000 & -0.028 & 0.063 & -0.745 & 0.000 & -0.031 & 0.068 & -0.680 & 0.000 \\
\hline Extreme overleverage & 0.035 & 0.077 & 0.000 & 0.727 & 0.030 & 0.071 & 0.000 & 0.659 & 0.043 & 0.086 & 0.000 & 0.727 \\
\hline \multicolumn{13}{|l|}{ Control variables } \\
\hline Average past leverage & 0.195 & 0.184 & 0.000 & 0.810 & 0.182 & 0.164 & 0.000 & 0.810 & 0.214 & 0.210 & 0.000 & 0.810 \\
\hline Growth opportunities & 2.060 & 2.036 & 0.574 & 16.705 & 2.131 & 1.980 & 0.574 & 16.705 & 1.953 & 2.112 & 0.574 & 16.705 \\
\hline Firm size & 11.161 & 2.012 & 6.144 & 16.401 & 11.498 & 2.056 & 6.144 & 16.401 & 10.655 & 1.832 & 6.144 & 16.401 \\
\hline Profitability & 0.055 & 0.279 & -1.914 & 0.426 & 0.080 & 0.259 & -1.914 & 0.426 & 0.018 & 0.302 & -1.914 & 0.426 \\
\hline Stock return & 0.006 & 0.048 & -0.135 & 0.189 & 0.009 & 0.046 & -0.135 & 0.189 & 0.001 & 0.051 & -0.135 & 0.189 \\
\hline Cash ratio & 0.145 & 0.182 & 0.000 & 0.940 & 0.143 & 0.171 & 0.000 & 0.940 & 0.147 & 0.197 & 0.000 & 0.940 \\
\hline Firm diversification index & 0.233 & 0.266 & 0.000 & 0.863 & 0.253 & 0.271 & 0.000 & 0.863 & 0.204 & 0.255 & 0.000 & 0.855 \\
\hline Firm foreign experience & 0.245 & 0.261 & 0.000 & 0.843 & 0.273 & 0.264 & 0.000 & 0.843 & 0.201 & 0.250 & 0.000 & 0.831 \\
\hline Industry M\&A liquidity & 0.072 & 0.119 & 0.000 & 0.946 & 0.077 & 0.128 & 0.000 & 0.946 & 0.065 & 0.103 & 0.000 & 0.946 \\
\hline Industry concentration & 0.110 & 0.112 & 0.019 & 0.811 & 0.110 & 0.112 & 0.019 & 0.811 & 0.111 & 0.112 & 0.019 & 0.810 \\
\hline Target industry sales growth & 0.039 & 0.126 & -0.417 & 0.631 & 0.042 & 0.134 & -0.417 & 0.631 & 0.035 & 0.114 & -0.417 & 0.631 \\
\hline \multicolumn{13}{|c|}{ PANEL B: Correlation matrix for the explanatory variables } \\
\hline Variables & (1) & (2) & (3) & (4) & (5) & (6) & (7) & (8) & (9) & (10) & (11) & (12) \\
\hline Leverage deviation (1) & 1.000 & & & & & & & & & & & \\
\hline Average past leverage (2) & $0.314^{\mathrm{a}}$ & 1.000 & & & & & & & & & & \\
\hline
\end{tabular}




\begin{tabular}{|c|c|c|c|c|c|c|c|c|c|c|c|c|}
\hline Growth opportunities (3) & $-0.013^{\mathrm{a}}$ & $-0.311^{\mathrm{a}}$ & 1.000 & & & & & & & & & \\
\hline Firm size (4) & 0.002 & $0.200^{\mathrm{a}}$ & $-0.225^{\mathrm{a}}$ & 1.000 & & & & & & & & \\
\hline Profitability (5) & 0.015 & -0.014 & $-0.209^{\mathrm{a}}$ & $0.345^{\mathrm{a}}$ & 1.000 & & & & & & & \\
\hline Stock return $(\mathbf{6})$ & $-0.022^{b}$ & $-0.166^{\mathrm{a}}$ & $0.157^{\mathrm{a}}$ & $0.024^{\mathrm{b}}$ & $0.171^{\mathrm{a}}$ & 1.000 & & & & & & \\
\hline Cash ratio $(7)$ & $-0.074^{\mathrm{a}}$ & $-0.404^{\mathrm{a}}$ & $0.332^{\mathrm{a}}$ & $-0.246^{\mathrm{a}}$ & $-0.243^{\mathrm{a}}$ & $0.020^{\mathrm{c}}$ & 1.000 & & & & & \\
\hline Firm diversification index (8) & 0.001 & $0.113^{\mathrm{a}}$ & $-0.105^{\mathrm{a}}$ & $0.359^{\mathrm{a}}$ & $0.111^{\mathrm{a}}$ & -0.012 & $-0.155^{\mathrm{a}}$ & 1.000 & & & & \\
\hline Firm foreign experience (9) & 0.004 & $0.038^{\mathrm{a}}$ & $-0.026^{\mathrm{a}}$ & $0.389^{\mathrm{a}}$ & $0.098^{\mathrm{a}}$ & -0.005 & $-0.025^{\mathrm{a}}$ & $0.248^{\mathrm{a}}$ & 1.000 & & & \\
\hline Industry M\&A liquidity (10) & -0.005 & $-0.065^{\mathrm{a}}$ & $0.174^{\mathrm{a}}$ & $-0.054^{\mathrm{a}}$ & $-0.023^{b}$ & $0.089^{\mathrm{a}}$ & $0.090^{\mathrm{a}}$ & -0.009 & -0.008 & 1.000 & & \\
\hline Industry concentration (11) & 0.001 & $-0.090^{\mathrm{a}}$ & $0.146^{\mathrm{a}}$ & $0.024^{\mathrm{b}}$ & $-0.105^{\mathrm{a}}$ & 0.009 & $0.168^{a}$ & $-0.046^{\mathrm{a}}$ & $0.023^{\mathrm{b}}$ & $0.175^{\mathrm{a}}$ & 1.000 & \\
\hline Target industry sales growth (12) & $-0.024^{b}$ & -0.014 & $0.094^{\mathrm{a}}$ & -0.012 & $0.024^{\mathrm{b}}$ & $0.069^{\mathrm{a}}$ & 0.015 & $-0.037^{\mathrm{a}}$ & $-0.046^{\mathrm{a}}$ & $0.145^{\mathrm{a}}$ & $0.079^{\mathrm{a}}$ & 1.000 \\
\hline
\end{tabular}

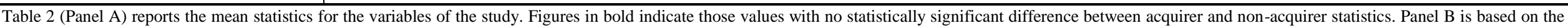
full sample, and a, b, and c represent statistical significance at $1 \%, 5 \%$, and $10 \%$, respectively. 
Table 3: Probit regressions on the relationship between acquisition probability and leverage deviation

\begin{tabular}{|c|c|c|c|c|}
\hline \multirow{2}{*}{ Models/Independent variables } & (1) & $(2)$ & (3) & (4) \\
\hline & All firms & Extreme deviant & Underleveraged & Overleveraged \\
\hline Leverage deviation & $\mathbf{- 0 . 0 9 4} * *(0.048)$ & $0.682 * *(0.280)$ & $0.433(0.278)$ & $0.875^{* * *}(0.284)$ \\
\hline Leverage deviation*Extreme deviant dummy & & $\mathbf{- 0 . 7 9 0 * * * ( 0 . 2 8 2 )}$ & & \\
\hline Extreme deviant dummy & & $-0.029 * *(0.011)$ & & \\
\hline Leverage deviation*Underleveraged firm dummy & & & $\mathbf{- 0 . 5 2 3} *(0.315)$ & \\
\hline Underleveraged firm dummy & & & $-0.028(0.020)$ & \\
\hline Leverage deviation*Overleveraged firm dummy & & & & $\mathbf{- 0 . 9 5 0} * * *(0.302)$ \\
\hline Overleveraged firm dummy & & & & $-0.016(0.021)$ \\
\hline Average past leverage & $-0.242 * * *(0.034)$ & $-0.240 * * *(0.035)$ & $-0.072(0.048)$ & $-0.352 * * *(0.043)$ \\
\hline Growth opportunities & $0.013 * * *(0.003)$ & $0.012 * * *(0.003)$ & $0.013 * * *(0.003)$ & $0.013 * * *(0.003)$ \\
\hline Firm size & $0.059 * * *(0.003)$ & $0.059 * * *(0.003)$ & $0.057 * * *(0.004)$ & $0.059 * * *(0.004)$ \\
\hline Profitability & $0.047 * *(0.022)$ & $0.049 * *(0.022)$ & $0.041 *(0.045)$ & $0.062 * *(0.026)$ \\
\hline Stock return & $0.451 * * *(0.121)$ & $0.409 * * *(0.122)$ & $0.429 * * *(0.142)$ & $0.253 *(0.146)$ \\
\hline Cash ratio & $-0.078 * *(0.034)$ & $-0.076 * *(0.034)$ & $-0.047(0.037)$ & $-0.087 * *(0.039)$ \\
\hline Firm diversification index & $-0.021(0.021)$ & $-0.021(0.021)$ & $-0.018(0.025)$ & $-0.006(0.025)$ \\
\hline Firm foreign experience & $0.071 * * *(0.023)$ & $0.071 * * *(0.023)$ & $0.092 * * *(0.026)$ & $0.051 *(0.026)$ \\
\hline Industry M\&A liquidity & $0.012(0.060)$ & $0.012(0.060)$ & $-0.026(0.065)$ & $0.006(0.069)$ \\
\hline Industry concentration & $-0.202(0.185)$ & $-0.199(0.184)$ & $-0.144(0.206)$ & $-0.337(0.219)$ \\
\hline Target industry sales growth & $0.116 * * *(0.043)$ & $0.115 * * *(0.043)$ & $0.144 * * *(0.049)$ & $0.132 * * *(0.050)$ \\
\hline Year dummies & Yes & Yes & Yes & Yes \\
\hline Industry dummies & Yes & Yes & Yes & Yes \\
\hline Number of observations & 9,749 & 9,749 & 7,313 & 7,312 \\
\hline Wald Chi-squared test & 879.02 & 887.80 & 617.09 & 712.46 \\
\hline Prob. > Chi-squared & 0.000 & 0.000 & 0.000 & 0.000 \\
\hline Pseudo $\mathbf{R}^{2}$ & 0.076 & 0.077 & 0.072 & 0.082 \\
\hline
\end{tabular}


Table 4: Probit regressions on the leverage deviation and acquisition probability nexus: The moderating effects

\begin{tabular}{|c|c|c|c|c|c|c|}
\hline \multirow{3}{*}{ Model/Independent variables } & (1) & (2) & (3) & (4) & (5) & (6) \\
\hline & \multicolumn{2}{|c|}{ Firm capabilities } & \multicolumn{2}{|c|}{ Industrial diversification } & \multicolumn{2}{|c|}{ Geographic diversification } \\
\hline & $\begin{array}{r}\text { High-growth } \\
\text { Firms } \\
\end{array}$ & $\begin{array}{r}\text { Low-growth } \\
\text { firms } \\
\end{array}$ & $\begin{array}{r}\text { Cross-industry } \\
\text { M\&As } \\
\end{array}$ & $\begin{array}{r}\text { Within-industry } \\
\text { M\&As } \\
\end{array}$ & $\begin{array}{r}\text { Cross-border } \\
\text { M\&As } \\
\end{array}$ & $\begin{array}{r}\text { Domestic } \\
\text { M\&As } \\
\end{array}$ \\
\hline Leverage deviation & $\mathbf{0 . 0 3 3}(0.111)$ & $\mathbf{- 0 . 1 8 5} * * *(0.055)$ & $\mathbf{0 . 0 0 9}(0.049)$ & $\mathbf{- 0 . 1 4 0 * * * ( 0 . 0 5 0 )}$ & $\mathbf{- 0 . 0 0 9}(0.051)$ & $\mathbf{- 0 . 1 1 7 * *}(0.049)$ \\
\hline Average past leverage & $-0.284 * * *(0.100)$ & $-0.128 * * *(0.040)$ & $-0.180 * * *(0.034)$ & $-0.233 * * *(0.035)$ & $-0.288 * * *(0.036)$ & $-0.174 * * *(0.035)$ \\
\hline Growth opportunities & $0.004(0.004)$ & $0.147 * * *(0.019)$ & $0.010 * * *(0.003)$ & $0.009 * * *(0.003)$ & $0.017 * * *(0.003)$ & $0.002(0.003)$ \\
\hline Firm size & $0.042 * * *(0.006)$ & $0.062 * * *(0.004)$ & $0.043 * * *(0.003)$ & $0.062 * * *(0.003)$ & $0.068 * * *(0.003)$ & $0.036 * * *(0.003)$ \\
\hline Profitability & $0.064 * *(0.028)$ & $0.000(0.034)$ & $0.015(0.023)$ & $0.057 * *(0.024)$ & $0.016(0.024)$ & $0.055^{* *}(0.023)$ \\
\hline Stock return & $0.349 *(0.185)$ & $0.464 * * *(0.160)$ & $0.225 *(0.120)$ & $0.529 * * *(0.123)$ & $0.482 * * *(0.119)$ & $0.375 * * *(0.122)$ \\
\hline Cash ratio & $-0.138 * * *(0.047)$ & $-0.020(0.048)$ & $-0.047(0.033)$ & $-0.061 *(0.034)$ & $0.093 * * *(0.032)$ & $-0.101 * * *(0.034)$ \\
\hline Firm diversification index & $0.034(0.041)$ & $0.010(0.025)$ & $0.194 * * *(0.020)$ & $-0.140 * * *(0.021)$ & $-0.015(0.020)$ & $0.006(0.022)$ \\
\hline Firm foreign experience & $0.076 *(0.043)$ & $0.049 *(0.027)$ & $0.059 * * *(0.022)$ & $0.046 * *(0.023)$ & $0.477 * * *(0.021)$ & $-0.274 * * *(0.023)$ \\
\hline Industry M\&A liquidity & $-0.052(0.081)$ & $0.084(0.090)$ & $0.077(0.053)$ & $-0.017(0.059)$ & $0.048(0.054)$ & $0.069(0.058)$ \\
\hline Industry concentration & $-0.235(0.331)$ & $-0.142(0.235)$ & $-0.159(0.180)$ & $-0.148(0.186)$ & $-0.350 * *(0.172)$ & $0.125(0.190)$ \\
\hline Target industry sales growth & $0.044(0.077)$ & $0.109 *(0.053)$ & $0.016(0.042)$ & $0.084 *(0.045)$ & $0.028(0.042)$ & $0.093 * *(0.044)$ \\
\hline Year dummies & Yes & Yes & Yes & Yes & Yes & Yes \\
\hline Industry dummies & Yes & Yes & Yes & Yes & Yes & Yes \\
\hline Number of observations & 2,734 & 7,013 & 9,744 & 9,749 & 9,749 & 9,744 \\
\hline Wald Chi-squared test & 264.88 & 694.19 & 1316.40 & 799.65 & 1954.47 & 615.75 \\
\hline Prob. $>$ Chi-squared & 0.000 & 0.000 & 0.000 & 0.000 & 0.000 & 0.000 \\
\hline Pseudo $\mathbf{R}^{2}$ & 0.086 & 0.082 & 0.122 & 0.067 & 0.217 & 0.049 \\
\hline
\end{tabular}

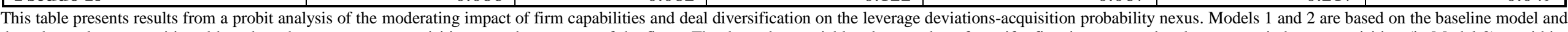

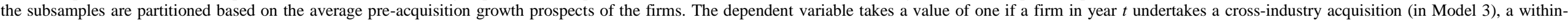

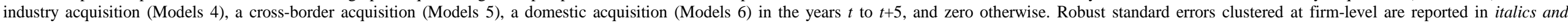
parentheses. All models include year and industry dummies. $* * *, * *$, and * represent statistical significance at $1 \%, 5 \%$, and $10 \%$, respectively. 
Table 5: Further analyses

\begin{tabular}{|c|c|c|c|c|c|c|c|c|c|}
\hline \multirow{3}{*}{$\begin{array}{l}\text { Model/Independent } \\
\text { variables }\end{array}$} & (1) & (2) & (3) & (4) & (5) & (6) & $(7)$ & (8) & (9) \\
\hline & Probit-CSA & Probit-Panel & \multicolumn{7}{|c|}{ Poisson regressions - Dependent variable is the number of acquisitions made } \\
\hline & $\begin{array}{r}\text { Multiple } \\
\text { acquisitions }\end{array}$ & $\begin{array}{r}\text { All } \\
\text { acquisitions }\end{array}$ & $\begin{array}{r}\text { All } \\
\text { acquisitions }\end{array}$ & $\begin{array}{r}\text { High-growth } \\
\text { Firms }\end{array}$ & $\begin{array}{r}\text { Low-growth } \\
\text { firms }\end{array}$ & $\begin{array}{r}\text { Cross-industry } \\
\text { acquisitions }\end{array}$ & $\begin{array}{r}\text { Within-industry } \\
\text { acquisitions }\end{array}$ & $\begin{array}{r}\text { Cross-border } \\
\text { acquisitions }\end{array}$ & $\begin{array}{r}\text { Domestic } \\
\text { acquisitions }\end{array}$ \\
\hline Leverage deviation & $\mathbf{- 0 . 1 2 8} * *(0.060)$ & $\mathbf{- 0 . 4 5 7 * * * * ( 0 . 1 9 9 )}$ & $\mathbf{- 0 . 2 0 8} * * *(0.076)$ & $\mathbf{- 0 . 4 7 6 * * *}(0.170)$ & $\mathbf{- 0 . 2 3 5 * * *}(0.087)$ & $\mathbf{0 . 0 1 4}(0.150)$ & $\mathbf{- 0 . 3 3 9} * * *(0.118)$ & $\mathbf{0 . 0 2 8}(0.166)$ & $\mathbf{- 0 . 2 6 9} * * *(0.101)$ \\
\hline Average past leverage & $-0.305 * * *(0.042)$ & $-1.894 * * *(0.220)$ & $-0.273 * * *(0.057)$ & $-0.153(0.174)$ & $-0.136 * *(0.067)$ & $-0.322 * * *(0.109)$ & $-0.274 * * *(0.095)$ & $-0.815 * * *(0.127)$ & $-0.036(0.075)$ \\
\hline Growth opportunities & $0.020 * * *(0.003)$ & $0.052 * *(0.017)$ & $0.016^{* * *}(0.004)$ & $0.014 * * *(0.005)$ & $0.169^{* * * *}(0.028)$ & $0.016 * *(0.008)$ & $0.012 *(0.006)$ & $0.035^{* * *}(0.008)$ & $-0.005(0.007)$ \\
\hline Firm size & $0.083 * * *(0.004)$ & $0.135 * * *(0.038)$ & $0.103 * * *(0.005)$ & $0.097 * * *(0.008)$ & $0.108 * * *(0.006)$ & $0.098 * * *(0.009)$ & $0.103 * * *(0.007)$ & $0.204 * * *(0.009)$ & $0.027 * * *(0.007)$ \\
\hline Profitability & $0.081 * * *(0.030)$ & $0.270 *(0.115)$ & $0.084 * *(0.036)$ & $0.055(0.049)$ & $0.068(0.053)$ & $0.069(0.070)$ & $0.147 * * *(0.057)$ & $0.012(0.077)$ & $0.119 * *(0.051)$ \\
\hline Stock return & $0.608 * * *(0.147)$ & $1.987 * * *(0.532)$ & $0.757 * * *(0.181)$ & $0.737 * * *(0.268)$ & $0.658 * * *(0.246)$ & $0.448(0.356)$ & $1.083 * * *(0.286)$ & $1.215 * * *(0.381)$ & $0.501 *(0.256)$ \\
\hline Cash ratio & $-0.086 * *(0.040)$ & $0.546 * *(0.225)$ & $-0.051(0.050)$ & $-0.173 * * *(0.069)$ & $0.098(0.070)$ & $0.048(0.105)$ & $-0.150 * *(0.075)$ & $0.376 * * *(0.100)$ & $-0.252 * * *(0.080)$ \\
\hline Firm diversification index & $0.005(0.023)$ & $-0.110(0.159)$ & $0.115 * * *(0.029)$ & $0.096 * *(0.052)$ & $0.123 * * *(0.035)$ & $0.672 * * *(0.055)$ & $-0.362 * * *(0.051)$ & $-0.097 *(0.056)$ & $0.256 * * *(0.045)$ \\
\hline Firm foreign experience & $0.058 * *(0.027)$ & $0.146(0.196)$ & $-0.021(0.032)$ & $-0.007(0.056)$ & $-0.056(0.039)$ & $0.098(0.060)$ & $-0.050(0.052)$ & $1.552 * * *(0.063)$ & $-1.260 * * *(0.056)$ \\
\hline Industry M\&A liquidity & $-0.012(0.072)$ & $0.251(0.261)$ & $0.009(0.083)$ & $-0.023(0.107)$ & $0.017(0.127)$ & $0.046(0.138)$ & $-0.097(0.121)$ & $-0.002(0.155)$ & $0.040(0.120)$ \\
\hline Industry concentration & $-0.286(0.212)$ & $0.204(0.992)$ & $-0.264(0.252)$ & $0.516(0.473)$ & $-0.777 * * *(0.325)$ & $-1.016^{*}(0.580)$ & $0.116(0.378)$ & $-0.312(0.372)$ & $-0.182(0.454)$ \\
\hline Target industry sales growth & $0.176 * * *(0.053)$ & $0.389 *(0.199)$ & $0.019(0.055)$ & $0.142(0.095)$ & $-0.081(0.069)$ & $-0.229 * *(0.099)$ & $0.218 * *(0.089)$ & $0.056(0.099)$ & $0.022(0.086)$ \\
\hline Year dummies & Yes & Yes & Yes & Yes & Yes & Yes & Yes & Yes & Yes \\
\hline Industry dummies & Yes & Yes & Yes & Yes & Yes & Yes & Yes & Yes & Yes \\
\hline Constant & & $0.282(0.717)$ & $-0.095(0.106)$ & $-0.308(0.201)$ & $-0.185(0.136)$ & $-1.338 * * *(0.244)$ & $-0.519 * * *(0.157)$ & $-2.325 * * *(0.162)$ & $-0.148(0.199)$ \\
\hline Number of observations & 7,640 & 9,749 & 5,858 & 1,791 & 4,067 & 5,858 & 5,858 & 5,858 & 5,858 \\
\hline Wald Chi-squared & 1095.60 & 248.25 & 4146.45 & 5273.04 & 9462.21 & 2618.84 & 894.42 & 3414.6 & 2091.27 \\
\hline Prob. > Chi-squared & 0.000 & 0.000 & 0.000 & 0.000 & 0.000 & 0.000 & 0.000 & 0.000 & 0.000 \\
\hline Pseudo R-squared & 0.128 & & 0.042 & 0.055 & 0.042 & 0.121 & 0.036 & 0.194 & 0.070 \\
\hline
\end{tabular}

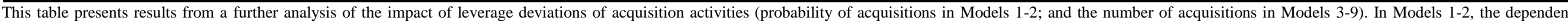

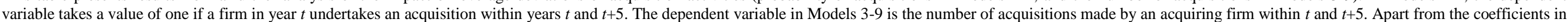

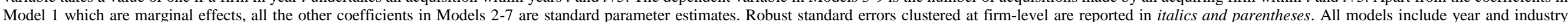
dummies. $* * *, * *$, and * represent statistical significance at $1 \%, 5 \%$, and $10 \%$, respectively. 